\title{
LA INTERPRETATIO PER ALIAM LEGEM COMO REGLA PARA DEFINIR EL SENTIDO DEL ARTÍCULO 2332 DEL CÓDIGO CIVIL, SOBRE PRESCRIPCIÓN DE LA ACCIÓN DE RESPONSABILIDAD EXTRACONTRACTUAL ${ }^{* * *}$
}

THE INTERPRETATIO PER ALIAM LEGEM AS A RULE TO

Define the meaning of Article 2332 of Chilean Civil Code,

OF LIMITATIONS FOR TORT INDEMNIFICATION ACTIONS

LE INTERPRETATIO PAR ALIAM LEGEM COMME UNE RĖGLE POUR DÉFINIR LE SENS DE L'ARTICle 2332 DU CODE CiVIL DE LA PRESCRIPTION DE LA RESPONSABILITÉ DÉLICTUELLE

Luis Valentín FerRada WalkeR ${ }^{* * *}$

\section{RESUMEN}

En este artículo se revisa la interpretación del término "perpetración del acto" considerado por el artículo 2332 del Código Civil chileno como hito inicial del cómputo de la prescripción de la acción de responsabilidad extracontractual, en conformidad a los dies a quo de otras normas que fijan plazos de prescripción extracontractual. Se concluye que la mayor parte de las normas análogas consideran para el inicio del cómputo el hecho material causante del perjuicio y no la evidencia del daño; que las escasas normas que consideran el daño, tienen en cuenta su manifestación objetiva y no su conocimiento por parte de la víctima, además de poseer, varias de ellas, un plazo máximo computado desde el hecho; y que los casos dudosos se deben a deficiencias en la técnica legislativa.

PalabRas CLAVE: Prescripción extracontractual - Acto - Daño - Interpretación por otras leyes

ABSTRACT

In this paper it is revised the meaning of "perpetration of the act" term that article 2332 of the Chilean Civil Code used as initial landmark of time of limitations for tort indemnification actions. The norm is compared with other norms about the same matter. We conclude that the majority of other norms begin their times of limitations

\footnotetext{
* El artículo fue aprobado para su publicación el 14 de septiembre de 2012.

** Este artículo es parte de un estudio iniciado el año 2003 y continuado hasta la fecha sobre la jurisprudencia, doctrina y sentido del artículo 2332 del Código Civil chileno, parcialmente incluido en la tesis de grado del autor ("De la prescripción extintiva extracontractual”, Universidad de los Andes, 2006, dirigida por el Prof. Hernán Corral Talciani).

${ }^{* * *}$ Abogado. Licenciado en Ciencias Jurídicas Universidad de los Andes. Candidato a Doctor en Derecho Universidad de Chile. Actualmente desarrolla su tesis doctoral y es profesor de Historia del Derecho en la Universidad San Sebastián. Becario Conicyt.
} 
in the fact that caused damage as starting point of their times of limitations, only consider its objective manifestation, but not the knowledge by the victims, and they also consider a maximum time since the fact that caused the damage; and, finally, that norms that are not clear about the starting point of their times of limitations, it is because of incorrect legislative technique.

KEY WORDS: Limitations for tort indemnification actions - Act - Damage - Interpretation by other norms

RÉSUMÉ

Cet article passe en revue l'interprétation de "perpétration de l'acte» considérépar l'article 2332 Code Civil chilien comme étape initiale pour calculer le délai de prescription de la responsabilité, conformément à la diez a quo d'autres règles établissant les délais de prescription extracontractuel. Nous concluons que la plupart des règles similaires pour calculer le début de la délai de prescription le act matériel qui provoque le préjudice et non les dommages. Quelques règles qui prennent en compte les dommages, considèrent sa manifestation objective et non leurs connaissances de la victime. Plusieurs d'entre eux, considèrent une période maximale calculée à partir de l'acte, et que les cas douteux sont dues à des déficiences dans la technique législative.

Mots CLÉs: Prescription délictuelle - Acte - Dommages - Autre interprétation des lois

\section{INTRODUCCIÓN}

"Las acciones que concede este título por daño o dolo, prescriben en cuatro años contados desde la perpetración del acto", artículo 2332 del Código Civil ${ }^{1}$.

"Los pasajes obscuros de una ley pueden ser ilustrados por medio de otras leyes, particularmente si versan sobre el mismo asunto", artículo 22 inciso 2o del Código Civil.

La principal discusión sobre el artículo 2332, regla general en la prescripción de la acción indemnizatoria extracontractual, se refiere a su dies a quo, al exacto significado y alcance del mandato de computar el plazo "desde la perpetración del acto", y a si este "acto" implica (i) exclusivamente el hecho material que provoca causalmente un daño, con independencia de la manifestación y conocimiento del perjuicio; o si (ii) es omnicomprensivo del daño, de modo que no hay acto mientras éste no se produce y es conocido por la víctima. Existe una tensión entre seguridad jurídica (dada por la primera interpretación) y justicia individual (garantizada por la segunda). Es un problema connatural a la prescripción extintiva, la que al tenor del artículo 2514 inciso $1^{\circ}$ se basa en dos elementos relativamente antagónicos: (i) el transcurso del plazo (asociado a la seguridad jurídica); y (ii) la inactividad de aquel contra quien se prescribe (lo que, en justicia hacia la víctima, implica que ésta conozca el daño y se encuentre en condiciones de accionar $)^{2}$. La prescripción liberatoria da preeminencia

\footnotetext{
${ }^{1}$ Salvo indicación en contrario, los artículos citados se refieren al Código Civil chileno (1855), según su texto vigente a la fecha.

${ }^{2}$ En tales elementos se basan las definiciones doctrinales de prescripción extintiva. Vid. Abeliuk ManASEVICH, René (1983). Las Obligaciones. Santiago: Editorial Jurídica Ediar-ConoSur, 2a Edición, p. 766; EsCalONA Riveros, Francisco (1997). La prescripción extintiva civil. Santiago: Editorial Jurídica ConoSur, Fundación
} 
al valor de la seguridad jurídica colectiva por sobre la justicia individual ${ }^{3}$; al elemento "transcurso del tiempo" por sobre el del "conocimiento del daño". Como señala el Mensaje del Código Civil: "Toda obligación personal que ha dejado de exigirse en el mismo espacio de tiempo [el plazo de la usucapión], perece" .

Pero lo cierto es que existe un debate sobre el significado del término "perpetración del acto"; sobre si el cómputo del plazo se inicia en un momento cierto pero más exigente e incluso injusto para la víctima (el hecho) o incierto pero más favorable para ella (la manifestación y conocimiento del daño) ${ }^{5}$. Esta discusión se encuentra además contaminada con la emotividad de nuestra época, donde la solidaridad con las víctimas (reales o potenciales) lleva a buscar interpretaciones del Derecho que las favorezcan ${ }^{6}$.

Intentando escapar de aquel influjo emotivo (que en definitiva afecta el carácter científico del Derecho) he optado por volver a los viejos elementos hermenéuticos del Código Civil.

Sin perjuicio que nos centraremos en el denominado elemento sistemático ${ }^{7}$ consagrado en el artículo 22 inciso $2^{\circ}$, no puede perderse de vista que la interpretación de una norma es un único acto complejo, y que el análisis de sus diversos elementos no es secuencial ni independiente entre sí, sino que todos ellos deben ser considerados dentro de un mismo proceso analítico ${ }^{8}$.

Fernando Fueyo, p. 5; Meza Barros, Ramón (2004). Manual de Derecho Civil. De las Obligaciones. Santiago: Editorial Jurídica de Chile, reimpresión de la 9a Edición actualizada.

Meza Barros, Ramón (2004). Manual de Derecho Civil. De las Obligaciones. Santiago: Editorial Jurídica de Chile, reimpresión de la 9a Edición actualizada, p. 455.

${ }^{3}$ Díaz-Ambrona Bardají, María Dolores (2000). Cuestiones sobre Responsabilidad Civil. En: Estudios de la UNED, Díaz-Ambrona Bardají, María Dolores (Coord.), Universidad Nacional de Educación a Distancia, Madrid, p. 73.

${ }^{4}$ Mensaje del Código Civil, párrafo 41º, de 22 de noviembre de 1855.

${ }^{5}$ Un resumen de las posturas que instan por una interpretación comprensiva del daño, en ELORRIAGA DE BonIs, Fabián (2008). "El día de inicio del plazo de prescripción de una acción indemnizatoria cuando el perjuicio se ha manifestado con posterioridad al hecho que lo origina”. En: Estudios de Derecho Civil III. Jornadas Nacionales de Derecho Civil, Valparaíso, 2007, GuZMÁn BrITo, Alejandro (Ed.), Pontificia Universidad Católica de Valparaíso, Santiago: LegalPublishing, pp. 771-789.

${ }^{6}$ Cfr. Barros Bourie, Enrique (2011). "Conceptualismo y vulgarismo en el Derecho civil. Homenaje a los 20 años de las Jornadas Nacionales de Derecho Civil”. En: Estudios de Derecho Civil VI: Jornadas Nacionales de Derecho Civil, Olmué, 2010, Figueroa, Gonzalo; Barros, Enrique y Tapia, Mauricio (Coords.), Universidad de Chile, Santiago: AbeledoPerrot LegalPublishing, pp. 21-36.

${ }^{7}$ Vid. Alessandri, Arturo; Somarriva, Manuel y Vodanovic, Antonio (1990). Derecho Civil, Parte Preliminar y Parte General. Santiago: Editorial Jurídica Ediar-ConoSur, T. I, 5ª Edición, p. 176.

${ }^{8}$ Vid. GuZmán Brito, Alejandro (2007). Las reglas del Código Civil del Chile sobre interpretación de la leyes. Santiago: LexisNexis, pp. 210-211. Sobre la perspectiva histórica (artículo 19 inciso 2º en la interpretación de la norma de prescripción de la acción de responsabilidad extracontractual, Vid. FerRAdA WaLKer, Luis Valentín (2011). "Aspectos históricos del art. 2332 del Código Civil, hacia la recta interpretación del precepto". En: Estudios de Derecho Civil VI: Jornadas Nacionales de Derecho Civil, Olmué, 2010, FigueroA, Gonzalo; Barros, Enrique y TAPIA, Mauricio (Coords.), Universidad de Chile, Santiago: AbeledoPerrot LegalPublishing, pp. 719-735. 
Tampoco pueden minusvalorarse las críticas a la interpretación exegética, algunas de las que comparto, aunque sigo creyendo que una interpretación a base de criterios objetivos (o tanto como se pueda), es el mejor modo de descubrir el auténtico sentido de la ley, evitando arbitrariedades y resoluciones aleatorias, garantizando la igual protección de las personas, la seguridad jurídica, la previsibilidad de las sentencias, y, en definitiva, el imperio del Estado de Derecho. Ni puede olvidarse que, a efectos de la interpretación judicial, las reglas de los artículos 19 a 24 son de aplicación obligatoria, no son facultativas ni representan meros consejos?

Es indudable que las normas de interpretación de la ley no arrojan necesariamente una única respuesta correcta, pero sí limitan las admisibles, acotan las alternativas entre las cuales el intérprete (el juez) puede elegir. Además, ante el requerimiento de fundamentar una decisión jurídica, es necesario esforzarse en justificarla como si fuera la única respuesta correcta, aunque se esté consciente que no lo es ${ }^{10}$. Así, aunque ella no exista, debe argumentarse y fundamentarse la pretensión que hay una única respuesta correcta, pues de lo contrario carecería de sentido todo razonamiento práctico ${ }^{11}$. Por lo demás, al menos desde la perspectiva del Derecho positivo chileno, la pretensión de una interpretación correcta tiene un sustento normativo. Así se desprende de la frase final del artículo 64 inciso $5^{\circ}$ de la Constitución Política, cuando autorizando al Presidente de la República a dictar textos refundidos de las leyes le previene que las modificaciones que se haga a las normas con ese motivo no pueden alterar, "en caso alguno, su verdadero sentido y alcance". De esto se colige que para el Constituyente cada norma tiene efectivamente un sentido verdadero, existiendo en consecuencia eventuales interpretaciones que se alejan de él.

Una de las reglas de interpretación legal que nos permite descubrir este sentido es la ilustración "por medio de otras leyes, particularmente si versan sobre el mismo asunto" (artículo 22 inciso $2^{\circ}$ ).

\section{Planteamiento del problema}

Los códigos decimonónicos, frutos del racionalismo jurídico de los siglos XVII y XVIII, pretendieron ser un correctivo a las antiguas compilaciones de leyes y al arbitrio de los jueces, y establecer mandatos evidentes que no requirieran interpretación ni explicación alguna ${ }^{12}$. En este sentido, señala el Mensaje del Código Civil, en la materia que aquí nos interesa, referida a la prescripción, que "el tiempo es un

\footnotetext{
${ }^{9}$ Alessandri, Somarriva y Vodanovic (1990), pp. 17-18.

${ }^{10}$ Vid. Squella Narducci, Agustín (2006). "Justificar decisiones jurídicas y justificar decisiones judiciales". Revista de Derecho, Universidad Austral de Chile, Vol. XIX, No 1, pp. 277-292.

${ }^{11}$ Vid. Alexy, Robert (1989). Teoría de la argumentación jurídica. Madrid: Centro de Estudios Constitucionales, p. 302.

${ }^{12}$ Como expresara Bello en El Araucano, la codificación era un paso previo ineludible sin el cual "habrá siempre incertidumbre y vacilación en los jueces, arbitrariedad e inconsecuencia en los juicios”, BELLO (1833), Andrés. "Codificación del Derecho Civil". El Araucano, recogido en SQuella Narducci, Agustín (2005). Andrés Bello. Escritos jurídicos, políticos y universitarios. Santiago: LexisNexis, 2a Edición, p. 43.
} 
elemento de tantas consecuencias en las relaciones juridicas, y ha dado motivo a tantas divergencias en las decisiones de las judicaturas y en la doctrina de los jurisconsultos, que no se ha creido superfluo fijar reglas uniformes, a primera vista minuciosas, para determinar el punto preciso en que nacen y expiran los derechos y las obligaciones en que este elemento figura"13.

La aplicación de la ley codificada a casos concretos demostró que no era posible congeniar con la realidad este ideal de una claridad tal que hiciera innecesaria la interpretación. El razonamiento jurídico es un razonamiento práctico porque busca decidir una acción (dictar una resolución) mediante la conjunción de una premisa normativa con una premisa fáctica. Esto exige, siempre, interpretar el adecuado sentido de la primera a fin de obtener una inferencia correcta ${ }^{14}$. Cada vez que se aplica una norma ella debe ser interpretada.

Uno de los métodos interpretativos que considera el Código Civil es la interpretatio per aliam legem conjugado con el criterio de substrata materia, esto es, "por medio de otras leyes, particularmente si versan sobre el mismo asunto" (artículo 22 inciso $2^{\circ}$ ). La norma exige, además, que nos encontremos frente a un "pasaje obscuro de la ley”. No estimo que este sea el caso del artículo 2332, pero es claro que muchos juristas actuales así lo piensan, o al menos han utilizado ese argumento para hacer admisibles las interpretaciones que plantean.

El citado criterio interpretativo tiene un antiguo origen. En los trabajos de Andrés Bello para la elaboración del Código Civil realizados en la década de 1830, él aparece consignado ya en el artículo 15 inciso $2^{\circ}$ del "Anteproyecto manuscrito" manteniéndose con igual tenor en el artículo 19 inciso $2^{\circ}$ del Proyecto de 1853. En el Proyecto Inédito se eliminó la referencia que se hacía a la "costumbre" y se enumeró como artículo 22 inciso $2^{\circ}$, siendo así conservado en el Proyecto de 1855 y en el Código Civil promulgado, versión hoy vigente. En nota marginal, Bello cita como fuente al artículo 17 del Código Civil de Luisiana, de texto muy similar ${ }^{16}$; vinculándolo también con la ley Incivile est (Dig. 1, 3, 24). En el Código Civil francés no existe una norma similar, aunque sí la hubo en sus proyectos, especialmente en el del año VIII (1800), fuente del Código Civil de Luisiana. Entre los autores que inspiraron a Bello en su trabajo codificador, Domat destaca la importancia de este criterio interpretativo ${ }^{17}$. También lo hacen, en el ámbito del Derecho Internacional, Vattel y Wolf, autores a quienes siguió en sus primeras

\footnotetext{
${ }^{13}$ Mensaje del Código Civil, párrafo 5º, de 22 de noviembre de 1855.

${ }^{14}$ SQuella (2006), pp. 277-292.

${ }^{15}$ Artículo 15 inciso $2^{\circ}$ del Anteproyecto Manuscrito: "Los pasajes obscuros de una ley pueden ser ilustrados por medio de otras leyes, o de costumbres que tengan fuerza ley; particularmente si versan sobre el mismo asunto".

${ }^{16}$ Actual artículo 13 del Código Civil de Luisiana: "Laws on the same subject matter must be interpreted in reference to each other".

${ }^{17}$ Vid. GuZmán Brito, Alejandro (2004). "La doctrina de Jean Domat sobre la interpretación de las leyes". Revista Chilena de Derecho, Universidad Católica de Chile, Santiago, Vol. 31, No 1, pp. 39-68.
} 
aproximaciones al tema de la interpretación de las normas ${ }^{18}$. El origen remoto de esta regla de analogía interpretativa se encuentra en el Derecho Romano, reflejándose en las fuentes del Dig. 1, 3, 26; Dig. 1, 3, 27, y Dig. 1, 3, $28^{19}$.

\section{Normas DiVERSAS AL ARTí́CUlO 2332 \\ DEL CÓDIGO CIVIL QUE FIJAN PRESCRIPCIONES LIBERATORIAS EXTRACONTRACTUALES}

A pesar de lo enunciado por el artículo 2332, sobre que tal prescripción se aplicaría a todas las acciones concedidas por el Título XXXV del Libro IV referidas a daño o dolo, y de lo amplio que esto resulta al tenor de los artículos 2314, 2320, 2329, entre otros, existe una serie de hipótesis legales de acciones judiciales que, no obstante emanar de delito o cuasidelito, o de una situación fáctica que admita tal clasificación, y tener por objeto la reparación del daño, poseen un plazo de prescripción propio (mayor, menor o idéntico al del artículo 2332) ${ }^{20}$. Una de las causas de esto es el proceso de "descodificación" provocado por las soluciones legislativas que desde mediados del siglo XX se ha dado a las problemáticas sociales del posmodernismo, origen de una serie de regímenes especiales de responsabilidad civil extracontractual ${ }^{21}$.

De este modo, hay múltiples normas que consagran acciones indemnizatorias en el ámbito extracontractual22, tanto en el Código Civil como en leyes especiales. Algunas, (i) conceden acciones y fijan reglas propias de prescripción, y otras (ii) conceden acciones a las que, a falta de norma específica, se aplica supletoriamente el artículo $2332^{23}$. En este trabajo consideraremos únicamente las primeras y, en

\footnotetext{
${ }^{18}$ Vid. GuZmán Brito (2007), pp. 10-12.

${ }^{19}$ Por todo, Guzmán Brito (2007), pp. 143-147. Véase también, GuZmán Brito, Alejandro (2009). "Las fuentes de las normas sobre interpretación de las leyes del 'Digeste des Lois Civiles' ('Code Civil') de la Luisiana (1808/1825)”. Revista de Estudios Histórico-Jurídicos, No 31, pp. 171-195; y GuZMÁn BRITO, Alejandro (1992). "La historia dogmática de las normas sobre interpretación recibidas por el Código Civil de Chile". En: Interpretación, integración y razonamiento jurídico. Conferencias y ponencias presentadas en el Congreso realizado en Santiago y Viña del Mar entre el 23 y 25 de mayo de 1991, Universidad de Chile, Universidad Adolfo Ibáñez, Santiago: Editorial Jurídica de Chile, pp. 41-87.

${ }^{20}$ Alessandri Rodríguez, Arturo (1943). De la Responsabilidad Extracontractual en el Derecho Civil Chileno. Santiago: Imprenta Universitaria, p. 525.

${ }^{21}$ Vid. Díez-Picazo y Ponce de León, Luis (2000). Derecho de Daños. Madrid: Civitas Ediciones, reimpresión de la $1^{\text {a }}$ Edición, pp. 127-157; Corral TAlCiani, Hernán (2003). Lecciones de Responsabilidad Civil Extracontractual. Santiago: Editorial Jurídica de Chile, en especial, "La sectorización de la responsabilidad sin culpa y su acotamiento legal" (p. 221) y "Los sistemas sectoriales de responsabilidad civil extracontractual” (pp. 251-313); Fernández Madero, Jaime (2002). Derecho de daños. Nuevos aspectos doctrinales y jurisprudenciales. Buenos Aires: La Ley, pp. 703-723.

${ }^{22}$ Sobre la definición de acción de responsabilidad extracontractual, Vid. CORRAL (2003), p. 20; LunA YerGA, Álvaro et al. (2002). "Reparación in natura y por equivalente: opciones de la víctima en el derecho español". Indret, No 2. Disponible en: <http://www.indret.com/pdf/083_es.pdf> [consulta: 17 mayo 2012].

${ }^{23}$ En causa Herrera con Sánchez la Corte de Apelaciones de Santiago reconoció expresamente la pertinencia de la aplicación supletoria del artículo 2332 respecto a las leyes especiales (Corte de Apelaciones de Santiago, "Herrera con Sánchez", 31 de enero de 1995 (indemnización de perjuicios), Revista de Derecho y Jurisprudencia, t. XCII, sec. $2^{\mathrm{a}}$, p. 11).
} 
especial, aquellas en que el dies a quo genera una mayor problemática respecto al artículo 2332 o que, por el contrario, reafirma su interpretación más tradicional de "perpetración del acto" como "hecho material que provoca el daño, con independencia de su manifestación".

\subsection{Otras normas en el Código Civil}

1) La acción reivindicatoria, a pesar de ser real, puede mutar en acción de indemnización de todo perjuicio si el obligado a reivindicar una especie la ha enajenado a sabiendas que era ajena (artículo 898 inciso $1^{\circ}$ frase final). Esta acción se extingue por la prescripción adquisitiva que el tercero haga del bien (artículo 2517). Si hay posesión regular y justo título (artículos 702-707) se extinguirá (i) en dos años, bienes muebles, y (ii) en cinco, bienes inmuebles (artículo 2508); en caso contrario, (iii) en diez años, prescripción adquisitiva extraordinaria (artículos 2510 y 2511); sin embargo, respecto un bien raíz inscrito, cuya primitiva inscripción no se hubiere cancelado, (iv) la acción sería imprescriptible (artículo 2505) 24 $^{2}$ En los casos en que la acción prescribe, el plazo se computa desde que se ha iniciado la posesión (artículos 717-720), lo que implica un hecho positivo ejecutado en un momento cierto.

2) Las acciones posesorias consideran también hipótesis de indemnización de los perjuicios causados por la perturbación de la posesión (artículos 921, 926, 927 y 928 inciso $2^{\circ}$ ). Las acciones indemnizatorias vinculadas a la querella de amparo y a la de restitución prescriben en un año completo contado desde el acto de molestia o embarazo a la posesión cuando su objeto sea conservarla; desde que el poseedor anterior la ha perdido, cuando sea recuperarla; y desde el último acto de violencia o desde que haya cesado la clandestinidad, si la nueva posesión ha sido violenta o clandestina (artículo 920). La acción indemnizatoria de la querella de restablecimiento (artículo 928) prescribe en seis meses contados desde el último acto de violencia (por aplicación del artículo 920). En todos los casos se trata de momentos ciertos (hechos).

En las acciones posesorias el término "acto" se emplea en idéntico sentido que en el artículo 2332.

3) La acción indemnizatoria de los vecinos por la ruina de un edificio por la omisión de reparaciones o la falta de cuidad del dueño, o en general por los peligros derivados de construcciones, árboles mal arraigados, etc., se rige por las normas de las acciones posesorias especiales, cuya prescripción extintiva es de un año completo computado desde que el edificio, construcción o árbol cayere por efecto de su mala condición o arraigo (artículos 932-946, y artículo 950), esto es, el dies a quo es un momento cierto (hecho). Para los otros terceros afectados (no vecinos)

\footnotetext{
${ }^{24}$ Hipótesis factible en nuestro derecho por la distinción entre los títulos traslaticios de dominio y los modos de adquirir.
} 
se aplica el artículo 2332 (artículo 2323). Así lo ha fallado expresamente la Corte Suprema, 3 de noviembre de 1997, "Aguirre con Fisco"25.

\subsection{Normas de prescripción extracontractual en otras leyes}

Existe un variado y disperso elenco de otras leyes que conceden acciones indemnizatorias y contemplan plazos propios de prescripción, entre otras, las siguientes:

1) La acción propiamente extracontractual que contempla el Código Aeronáutico es aquella en beneficio de terceros por los daños ocasionados en la superficie a consecuencia de algún evento ocurrido a una aeronave en vuelo, o por aquello que caiga o se desprenda de ella. La acción prescribe en un año, contado desde el día de ocurrencia de los hechos (artículo 175 de la Ley No 18.916, Código Aeronáutico, de 8 de febrero de 1990).

2) La Ley Orgánica Constitucional de Estados de Excepción establece ciertas hipótesis cuasi-expropiatorias y otras propiamente indemnizatorias, las que prescriben en un año contado desde la fecha de término del estado de excepción (artículos 17-20 de la Ley No 18.415, Orgánica Constitucional de Estados de Excepción, de 14 de junio de 1985).

3) La Ley de Bases Generales del Medioambiente, dispone que las acciones ambientales y civiles de responsabilidad por daño ambiental, prescribirán en el plazo de cinco años, contado desde la manifestación evidente del daño (artículo 63 de la Ley No 19.300, de Bases Generales del Medioambiente, de 9 de marzo de 1994).

Debe destacarse, que se refiere a una "manifestación" objetiva, con prescindencia del "conocimiento", criterio que intentó introducirse en la Cámara de Diputados y que fue explícitamente descartado en el tercer trámite legislativo por dar "lugar a incertidumbre e inestabilidad jurídica" 26 .

La opción legislativa de considerar el dies a quo en la manifestación del daño y no en el hecho que lo causa ha sido criticada porque crearía una situación de falta de certeza jurídica que haría perder sentido a la prescripción ${ }^{27}$, pero ha sido también defendida en atención a los alcances y características del daño ambiental ${ }^{28}$. Se han planteado, asimismo, algunas dudas sobre la aplicación de la prescripción del artículo 63 de la Ley No 19.300 (1994), ya que la misma ley, en su artículo 51 inciso $3^{\circ}$, hace una remisión supletoria, en materia de responsabilidad civil, al

\footnotetext{
${ }^{25}$ Sentencia Corte Suprema, "Aguirre con Fisco", 3 de noviembre de 1997 (indemnización de perjuicios), Rol 4306-1996, LegalPublishing No 14940.

26 Pizarro Torrealba, Eduardo y Pino Reyes, Octavio (2001). Responsabilidad civil extracontractual por daño ambiental. Santiago: Editorial Jurídica ConoSur, pp. 113-116.

${ }^{27}$ Ortúzar Solar, Antonio (1994). "Chile ingresa al derecho ambiental”. Revista del Abogado, Colegio de Abogados de Chile, Santiago, julio de 1994, p. 27.

${ }^{28}$ Pizarro y Pino (2001), pp. 118-119.
} 
Título XXXV del Libro IV del Código Civil, donde se encuentra el artículo 2332, norma no derogada de modo expreso y, en la argumentación de algunos autores, tampoco tácito. En realidad, es un problema de mala técnica legislativa.

4) El Código de Comercio en su Libro III, "De la navegación y el comercio marítimo", consagra acciones indemnizatorias con plazos de prescripción propios, algunas de las cuales pueden ser extracontractuales. Así, las acciones relativas al abordaje ${ }^{29}$, prescriben en dos años contados desde la fecha del accidente. Será de tres años si la nave responsable no pudo ser retenida o demandada mientras estaba en aguas jurisdiccionales, abandonándolas sin recalar en puertos chilenos (artículos 1116, 1121-1125, 1248 y 1249 del Código de Comercio, según modificación introducida por Ley No 18.680, de 11 de enero de 1988). Respecto a la avería simple o particular ${ }^{30}$, el propietario de la cosa dañada debe soportarla, sin perjuicio de perseguir las responsabilidades que corresponda. Estas acciones prescriben en dos años, al encontrarse entre "todas las demás acciones que procedan de las obligaciones de que trata este Libro [III], a las que no se haya señalado un plazo especial'. Por un presumible error legislativo no se indica el dies a quo, debiendo entenderse que es desde el hecho que causa el daño, por aplicación de la regla del abordaje, acontecimiento más similar (artículos 1087, 1093, 1094, 1248 y 1249 del Código de Comercio).

5) La Ley de Navegación Marítima concede acciones de responsabilidad civil por tres causas, pero sólo fija plazo a la por derrame de hidrocarburos y otras sustancias nocivas, y en general por contaminación desde naves, o para el reembolso de gastos para prevenir o disminuir dichos daños, la que prescribe en tres años, contados desde la fecha en que se produjo el daño o se realizaron los actos que dan acción de reembolso, aunque no podrá interponerse acción alguna después de seis años desde la fecha del siniestro. Si éste consiste en una serie de acontecimientos, el plazo se cuenta desde la fecha inicial del más antiguo (artículos 142-145 y 146 inciso $5^{\circ} \mathrm{del}$ D.L. No 2.222, sobre Navegación Marítima, de 31 de mayo de 1978).

En cuanto al dies a quo, debe precisarse que ellos son dos, y de distinta naturaleza (aunque la norma los consigna sin mayor diferenciación). En efecto, uno de ellos se refiere a la fecha en que se produjo el daño, pudiendo considerarse como equivalente al hito de "manifestación del daño" que tiene en cuenta el artículo 63 de Ley No 19.300 (1994), aunque sería necesario dilucidar si la fecha de "producción” de

\footnotetext{
${ }^{29}$ Situación que de acuerdo al artículo 1116 del Código de Comercio puede definirse como la colisión o proximidad de colisión entre dos o más naves o artefactos navales causado por su movimiento autónomo o al ser desplazadas por el oleaje, que provoca daño a alguna de tales embarcaciones, a sus cargas o a las personas a bordo.

${ }^{30}$ Situación que de acuerdo al artículo 1093 del Código de Comercio puede definirse como los daños o pérdidas que afecten a la nave o a la carga, por fuerza mayor o caso fortuito, por vicio propio o por actos o hechos del cargador, del naviero, sus dependientes o terceros; los gastos extraordinarios e imprevistos incurridos en beneficio exclusivo de la nave, de la carga o de una parte de ésta; y en general, todos los daños y gastos extraordinarios e imprevistos que no merezcan la calificación de avería común.
} 
un daño es necesariamente la misma de su "manifestación" sensible, o si acaso un "hecho" puede producir un daño aun antes que éste sea humanamente detectable desplegando un cuidado ordinario. No obstante, el establecimiento de un plazo máximo lleva a concluir que este dies a quo se refiere a la manifestación sensible del daño (porque si no el plazo máximo carecería de sentido). El otro cómputo se inicia en la fecha en que se realizaron los actos que dan acción de reembolso, que es un momento determinado, un "hecho".

En lo relativo a que ante una serie de acontecimientos el plazo se cuente desde el más antiguo, esta es una regla contradictoria con el principio general aplicado a una serie de actos que causan daño, en que se considera el más reciente $^{31}$, pero es coherente con las normas de daño ambiental, por cuanto al indicar el artículo 63 de Ley No 19.300 (1994) que la prescripción se computa desde la manifestación evidente del daño hace alusión al momento más antiguo en que él se evidencia.

La acción por abordaje de la Ley de Navegación Marítima no contempla término extintivo, debiendo aplicarse en principio el plazo considerado por el Libro III del Código de Comercio, para el mismo evento, de dos años desde la fecha del accidente o tres años si la nave no ha podido ser retenida (artículo 118 del D.L. No 2.222 (1978), y 1248 y 1249 del Código de Comercio).

La acción contra el dueño de instalaciones terrestres que produzcan daños al ambiente marino por vertimiento o derrame de sustancias contaminantes no indica plazo de prescripción (artículo 147 del D.L. No 2.222 (1978)), ni tampoco es evidente el que corresponda aplicar, existiendo concurso de leyes entre el artículo 146 de la Ley de Navegación Marítima (1978), sobre contaminación desde naves (tres años, contados desde la fecha en que se produjo el daño o se realizaron los actos que dan acción de reembolso, con un plazo máximo de seis años desde la fecha del siniestro); el artículo 63 de la Ley de Bases Generales del Medioambiente (1994), también sobre daño ambiental (cinco años desde la manifestación evidente del daño); y eventualmente el artículo 2332 (cuatro años desde la perpetración del acto). Estimamos debiera preferirse la primera (artículo 22 inciso $1^{\circ}$ ), aunque el punto es discutible.

\footnotetext{
${ }^{31}$ La Corte Suprema ha resuelto que, tratándose de hechos ilícitos concatenados entre sí, los cuales en definitiva conforman un solo ilícito mayor, la prescripción debe correr desde el último acto que los conforma (Corte Suprema, "Recurso de queja presentado por Kimpel", 6 de noviembre de 1981 (recurso de queja), Revista de Derecho y Jurisprudencia, t. LXXVIII, sec. 5a, p. 326). La doctrina ha apoyado este criterio al estimar que, cuando el hecho ilícito consta de varias acciones, el plazo debe contarse cuando concluye el período de ejecución (Corral (2003), p. 350). En estos eventos, la ilicitud sería persistente, y mientras ésta subsiste, se estaría perpetrando el delito o cuasidelito (RIOseco EnRíQuez, Emilio (2004). La prescripción extintiva ante la jurisprudencia. Santiago: Editorial Jurídica de Chile, 2a Edición actualizada, p. 114). De este modo, la perpetración se extendería en el tiempo y no terminaría sino cuando cese el ilícito, por cuanto, al referirse a un acto complejo, el momento del acto es la culminación completa de él (DOMínGUEZ Águila, Ramón (2004). La prescripción extintiva, Doctrina y jurisprudencia. Santiago: Editorial Jurídica de Chile, pp. 378 y 380).
} 
6) La Ley sobre Protección Agrícola, además de las indemnizaciones cuasiexpropiatorias (artículo 7o inciso 3º del D.L. No 3.557, sobre Protección Agrícola, de 9 de febrero de 1981), contempla tres acciones civiles, pero la regulación de su prescripción no es uniforme.

La acción de los sometidos a una actividad de control de plagas contra el Servicio Agrícola y Ganadero (SAG) o contra quienes éste haya designado para ejecutarla, a fin de reclamar por el daño emergente (los demás perjuicios no son indemnizables) causados en bienes u objetos anexos y diversos de los sometidos a tratamiento, ya sea en forma accidental o como consecuencia inevitable, prescribe en un año, contado desde que aparezcan de manifiesto los perjuicios producidos (artículo $8^{\circ} \mathrm{del}$ D.L. No 3.557 (1981)), en términos similares a la manifestación evidente del daño del artículo 63 de la Ley No 19.300 (1994).

La acción por daños que compete a personas diversas de aquellas cuyos bienes o propiedades están siendo tratados (terceros, en la terminología de la ley), provocados por la aplicación de plaguicidas, ya sea en forma accidental o como una consecuencia inevitable, prescribe en un año desde que se detecten los daños, limitándola por un plazo máximo de cuatro años desde la aplicación del plaguicida (artículo 36 del D.L. No 3.557 (1981)), según modificación introducida por la Ley No 20.308, sobre Protección a los Trabajadores en el Uso de Productos Fitosanitarios, de 27 de diciembre de 2008) ${ }^{32}$. Sin perjuicio que el verbo "detectar" remite al "conocimiento" de los daños por parte de la víctima, la eventual imprescriptibilidad que esto produce es morigerada por el establecimiento de un plazo máximo ${ }^{33}$.

En los artículos $8^{\circ}$ y 36 del D.L. No 3.557 (1981, 2008) son idénticos los plazos de prescripción (un año) y el dies a quo (desde que se manifiesten o aparezcan los daños). Difieren, sin embargo, en la legitimidad activa (los sometidos a tratamiento, en el primer caso; los terceros, en el segundo) y pasiva (organismos estatales o sus mandatarios, en el primer caso; los particulares, en el segundo). Pero, sin duda, la gran diferencia entre ambas acciones, es que la segunda establece un plazo máximo para impetrar la acción, limitación que no tiene la primera. Si bien el artículo 36 del D.L. No $3.557(1981,2008)$ no impide demandar al SAG (entidad estatal con personalidad jurídica y patrimonio propio $^{34}$ ), ni a otras reparticiones gubernamen-

\footnotetext{
${ }^{32}$ Hasta la Ley No 20.308, sobre Protección a los Trabajadores en el Uso de Productos Fitosanitarios, Diario Oficial, 27 de diciembre de 2008, el plazo máximo era de dos años desde la aplicación. La acción por los mismos hechos, en la anterior norma sobre la materia, hoy derogada, prescribía en un plazo único de un año, contado desde la fecha en que se produjere el daño (artículo 14 de Ley No 15.703, sobre Pesticidas, Diario Oficial, 1 de octubre de 1964, derogada por D.L. No 3.557 (1981)).

${ }^{33}$ Esta idea de una regla de prescripción que considerara el "conocimiento" del daño pero asociado a la existencia de un plazo máximo, que fue en definitiva rechazada, fue manifestada por Andrés Bello en los trabajos preparatorios del artículo 2.332, Vid. FerRada WaLKer (2011), pp. 732-733.

${ }^{34}$ Artículo $1^{\circ}$ de la Ley No 18.755 , sobre el Servicio Agrícola y Ganadero, Diario Oficial, 7 de enero de 1989.
} 
tales que eventualmente hayan dispuesto como medida de prevención o control la aplicación de plaguicidas, ateniéndose al tenor de las normas y a su ubicación ${ }^{35}$ es posible plantear que contra los organismos estatales se acciona conforme el artículo $8^{\circ}$ del D.L. No 3.557 (1981) y sólo contra los particulares de acuerdo al artículo 36 del D.L. No 3.557 (1981, 2008). Esta interpretación tiene, sin embargo, el grave inconveniente de contravenir el artículo 2497 del Código Civil, que dispone que las reglas relativas a la prescripción se aplican al Estado de la misma forma que a los particulares. Esto, por cuanto al no disponerse un límite temporal para que el daño se manifieste, la acción del artículo $8^{\circ}$ del D.L. No 3.557 (1981) se transforma en la práctica en imprescriptible. Ello traiciona el texto y espíritu de la propia norma, que de hecho está fijando un plazo de prescripción. Si bien el plazo máximo para impetrar la acción fue uno de los puntos específicamente debatido en la última modificación de esta norma (Ley No 20.308 (2008)), ello sólo se refirió al artículo 36 y no así al artículo $8^{\circ}$, ambos del D.L. № $3.557(1981,2008){ }^{36}$

Por otra parte, la acción indemnizatoria por la contaminación agrícola producida por las actividades y empresas artesanales, industriales, fabriles y mineras, no indica plazo de prescripción (artículo 12 del D.L. No 3.557 (1981)), existiendo un doble concurso de normas: (i) entre los preceptos de la misma Ley sobre Protección Agrícola que, como se ha visto, poseen diferencias que pueden ser significativas (artículos $8^{\circ}$ y 36 del D.L. No 3.557 (1981, 2008)), y (ii) difiriendo este supuesto de hecho de los otros casos regulados en la ley, podría ser pertinente aplicar las reglas generales, pero entonces existe concurso de normas entre (a) el artículo 2332 del Código Civil y (b) el artículo 63 de la Ley No 19.300 (1994).

7) La Ley sobre Seguridad Nuclear contempla acciones por los daños causados a personas y bienes contra el explotador de una instalación, planta, centro, laboratorio o establecimiento nuclear, y contra otras personas asimilables a él, tales como los transportistas de material radiactivo. Si bien algunas de ellas se rigen por el artículo 2332 (contra terceros que han sustraído, robado, etc., material radiactivo), o por las normas de la Ley No 16.744, de Seguro Social contra Riesgos de Accidentes del Trabajo y Enfermedades Profesionales, de 1 de febrero de 1968 (artículo 58 de Ley No 18.302, sobre Seguridad Nuclear, de 2 de mayo de 1984), el plazo general de prescripción de las restantes acciones al amparo de esta ley es de diez años contados desde la fecha en que ocurrió o se denunció por un inspector el accidente nuclear (artículo 66 de la Ley No 18.302 (1984)).

\footnotetext{
${ }^{35}$ El artículo $8^{\circ}$ del D.L. No 3.557, Ley sobre Protección Agrícola, Diario Oficial, 9 de febrero de 1981, se encuentra en el Título II de la norma, referido a la "Prevención, Control y Combate de Plagas", tarea expresamente encomendada en ese mismo título al SAG. Por su parte, el artículo 36 del D.L. No 3.557 (1981, 2008) se ubica en el Título III, sobre "Fabricación, Comercialización y Aplicación de Plaguicidas y Fertilizantes", donde se reglamenta en relación a los particulares.

${ }^{36}$ Historia de la Ley No 20.308 (2008). Sobre protección a los trabajadores en el uso de productos fitosanitarios. Biblioteca del Congreso Nacional de Chile, 27 de diciembre de 2008. Disponible en: <http://www.bcn.cl/ histley/lfs/hdl-20308/HL20308.pdf> [consulta: 17 mayo 2012].
} 
8) La Ley General de Urbanismo y Construcciones establece actualmente en sus artículos 18 y 19 un régimen especial de responsabilidad que puede ser tanto contractual como extracontractual ${ }^{37}$. Las acciones prescriben en plazos diversos según la entidad de los defectos: diez años, estructura soportante del inmueble; cinco años, elementos constructivos o de las instalaciones; tres años, terminaciones; y cinco años, defectos no numerados, computándose desde la fecha de la recepción definitiva de la obra por parte de la Dirección de Obras Municipales, salvo el de tres años, que se cuenta desde la fecha de la inscripción de la propiedad a nombre del comprador en el Conservados de Bienes Raices respectivo (artículo 18 del D.F.L. No 458, Nueva Ley General de Urbanismo y Construcciones, de 13 de abril de 1976, con múltiples modificaciones, la última de las cuales fue introducida por la Ley No 20.443, 23 de noviembre de 2010).

\subsection{Cinco casos especialmente interesantes}

Hay al menos tres normas que no podrían dejar de considerarse en este análisis, ya que corresponden a manifestaciones relativamente recientes del criterio del legislador respecto al dies a quo de la prescripción extracontractual; hay una cuarta norma que requiere ser explicada; y hay un proyecto de ley que no llegó a ser norma legal, pero que merece ser recordado.

1) La Ley No 19.301, que modificó diversas normas sobre valores, fondos mutuos, fondos de inversión y similares, de 19 de marzo de 1994, incorporó a la Ley No 18.045, de Mercado de Valores, de 22 de octubre de 1981, una acción indemnizatoria por los daños causados por el uso de información privilegiada. Originalmente, la acción prescribía en un año contado a partir de la fecha en que la información privilegiada hubiera sido divulgada al mercado y al público inversionista ${ }^{38}$. El precepto fue modificado por la Ley No 20.190, sobre Fomento de la Industria de Capital de Riesgo, de 5 de junio de 2007, a fin de extender el plazo de prescripción a cuatro años, manteniéndose el dies a quo en el hecho de la divulgación y no la de los eventuales daños ${ }^{39}$. Durante la discusión legislativa se manifestó en reiteradas ocasiones que se modificaba la norma para uniformarla con el artículo $2332^{40}$, alcanzándose el texto actual del artículo 172 inciso $2^{\circ}$ de la Ley No 18.045 (1981, 2007).

\footnotetext{
${ }_{37}$ Según modificaciones de la Ley No 19.472, que estableció normas relativas a la calidad de la construcción, Diario Oficial, 16 de septiembre de 1996; y de la Ley No 20.016, que estableció normas relativas a la calidad de la construcción, Diario Oficial, 27 de mayo de 2005.

${ }^{38}$ Artículo primero, letra b), artículo 172 inciso $2^{\circ}$, de la Ley № 19.301, que modificó diversas normas sobre valores, fondos mutuos, fondos de inversión y similares, Diario Oficial, 19 de marzo de 1994.

${ }^{39}$ Artículo 6, numeral 11, de Ley No 20.190, Introduce adecuaciones de índole tributaria e institucional para el fomento de la industria de capital de riesgo y continúa con la modernización del mercado de capitales, Diario Oficial, 5 de junio de 2007.

${ }^{40}$ Así lo manifestó el asesor del Ministerio de Hacienda que explicó el proyecto en la Comisión de Hacienda de la Cámara de Diputados, de igual manera fue consignado en el Primer Informe de la Comisión
} 
2) La Ley No 19.640, Orgánica Constitucional del Ministerio Público, de 15 de octubre de 1999, consagra acciones por la responsabilidad civil individual de sus funcionarios y de los fiscales por los actos que realicen en el ejercicio de sus funciones (artículos 11 y 45 de la Ley No 19.640 (1999)), las que se rigen por las normas generales; además, se estableció una acción especial de responsabilidad contra del Estado por las conductas injustificadamente erróneas o arbitrarias del Ministerio Público, la que prescribe en cuatro años desde la fecha de la actuación dañina (artículo 5o inciso 20 de la Ley No 19.640 (1999)) ${ }^{41}$.

El Mensaje no contemplaba esta última norma y sólo se refería a la responsabilidad civil de los fiscales en forma individual, además de contener imprecisiones y confusiones sobre la naturaleza jurídica del Ministerio Público. Una indicación del Ejecutivo en el segundo trámite legislativo introdujo el artículo $4^{\circ}$ bis, que corresponde en términos generales al actual artículo 5 de la Ley No 19.640 (1999). Difieren en que la norma original trataba de "actos" injustificadamente erróneos o arbitrarios, lo que fue reemplazado por "conductas", compresivas de acciones y omisiones; además de cambios menores de redacción. El inciso $2^{\circ}$, sobre la prescripción, no varió. En la discusión se manifestó que esta norma aclaraba la plena aplicación al Estado del plazo general de prescripción de la responsabilidad extracontractual, en referencia al artículo $2332^{42}$.

3) La Ley No 19.966, sobre Garantías en Salud (Plan de Garantías Explícitas de Salud, GES; ex AUGE), de 3 de septiembre de 2004, concede acción indemnizatoria contra las instituciones prestadoras de servicios de salud, la que prescribe en cuatro años contados desde la acción u omisión (artículo 40 de la Ley No 19.966 (2004)).

El Mensaje no contenía normas sobre responsabilidad en materia sanitaria, las que se incorporaron por indicación en el segundo trámite legislativo. El artículo 52 de la indicación del Ejecutivo disponía la prescripción de las acciones en dos años contados desde la acción u omisión. En el Senado se cuestionó que el plazo fuera menor al del artículo 2332 y la situación de los daños evidenciados

\footnotetext{
Hacienda del Senado, sin perjuicio de relacionarlo también con el artículo 822 del Código de Comercio y con el artículo 33 del D.L. No 3.538, que crea la Superintendencia de Valores y Seguros, Diario Oficial, 23 de diciembre de 1980, que regula la prescripción de la facultad sancionatoria de dicha entidad; y así fue entendido en la discución de esta última comisión. En definitiva, la modificación fue aprobada tal como la proponía el Mensaje. Por todo, Historia DE LA LEY No 20.190 (2007). Introduce adecuaciones de indole tributaria e institucional para el fomento de la industria de capital de riesgo y continúa con la modernización del mercado de capitales. Biblioteca del Congreso Nacional de Chile, 5 de junio de 2007. Disponible en: <http://www.bcn.cl/histley/lfs/hdl-20190/HL20190.pdf> [consulta: 17 mayo 2012].

${ }^{41}$ Mayores alcances sobre el tema en Dorn Garrido, Carlos (2005). "Responsabilidad extracontractual del Estado por actos del Ministerio Público". Revista de Derecho, Consejo de Defensa del Estado, No 13, s/p.

${ }^{42}$ Historia de la Ley No 19.640 (1999). Establece la ley orgánica constitucional del Ministerio Público. Biblioteca del Congreso Nacional de Chile, 15 de octubre de 1999, pp. 8, 10, 72, 79, 80, 97-100, 383, 424, 453, 454, 569, 570, 633, 639 y 831. Disponible en: <http://www.bcn.cl/histley/lfs/hdl-19640/HL19640. pdf> [consulta: 17 mayo 2012].
} 
una vez transcurrido el breve plazo. Se propuso como dies a quo la "manifestación del daño", lo que no fue acogido. En definitiva, se rechazó el artículo en la Comisión de Salud del Senado, a fin de que se aplicara la regla general del artículo 2332. Una nueva indicación, previa a la votación en la Sala del Senado, consideró un nuevo artículo con la numeración y texto vigentes (artículo 40 de la Ley No 19.966 (2004)). Así fue aprobado en tercer trámite legislativo y en definitiva promulgado ${ }^{43}$.

4) Suele señalarse que en el artículo 20 del D.L. No 211, Ley de Defensa de la Libre Competencia, de 22 de diciembre de 1973 (texto refundido por D.F.L. No 1 del Ministerio de Economía, Fomento y Reconstrucción, de 7 de marzo de 2005, última modificación introducida mediante Ley No 20.361 de 13 de julio de 2009) habría una excepción a la regla mayoritaria que considera como dies a quo el "hecho" que causa daño y no la manifestación del mismo ni su conocimiento. Sin embargo, dicha excepción es más aparente que real, quienes la alegan tienden a confundir las acciones sancionatorias que concede esta norma con las acciones propiamente civiles, y existen finalmente errores relativamente graves de técnica legislativa.

El artículo citado no existía en el texto original del D.L. No 211 (1973), siendo introducido, en una primera versión, mediante la Ley No 19.911, que creó el Tribunal de la Libre Competencia, de 14 de noviembre de 2003, misma norma que autorizó al Presidente de la República a fijar un texto refundido. El artículo 17 E de la Ley No 19.911 (2003), ubicado dentro del Párrafo 2 del nuevo Título II que se introducía al D.L. No 211 (1973), referido a las atribuciones y procedimientos del Tribunal de Defensa de la Libre Competencia, corresponde en general al actual artículo 20, al que posteriormente la Ley No 20.361 (2009) introdujo algunas modificaciones. Como se advierte de su ubicación dentro de la norma, por naturaleza es una regulación sancionatoria más que indemnizatoria, ya que se refiere a las atribuciones del Tribunal de Defensa de la Libre Competencia para aplicar sanciones.

Respecto a las acciones civiles, el D.L. No 211 (1973, 2009) en su conjunto presenta una redacción y técnica legislativa defectuosa. En el actual artículo 30 inciso $1^{\circ}$ (que corresponde al artículo 17 N de la Ley No 19.911 (2003)), se refiere a "la acción de indemnización de perjuicios a que haya lugar, con motivo de la dictación por el Tribunal de Defensa de la Libre Competencia de una sentencia definitiva ejecutoriada", dando pábulo a una interpretación eventualmente errónea en el sentido que tal acción nacería de la sentencia y no del "hecho" atentatorio a la libre competencia. No obstante, ello es aclarado en el inciso $2^{\circ}$ del mismo artículo, al disponer que el tribunal civil competente al "resolver sobre la indemni-

${ }^{43}$ Historia de La Ley No 19.966 (2004). Establece un régimen de garantías de salud. Biblioteca del Congreso Nacional de Chile, 3 de septiembre de 2004, pp. 7-40, 547-550, 552-553, 620, 635-636, 851, 959 y 1025. Disponible en: <http://www.bcn.cl/histley/lfs/hdl-19966/HL\%2019966.pdf> [consulta: 17 mayo 2012]. 
zación de perjuicios, fundará su fallo en las conductas, hechos y calificación jurídica de los mismos, establecidos en la sentencia del Tribunal de Defensa de la Libre Competencia". Esto es, lo que se busca es simplemente que ambas sentencias no sean contradictorias, en un modo equivalente a cuanto prescribe el artículo $180 \mathrm{del}$ Código de Procedimiento Civil en relación a las sentencias penales que produzca cosa juzgada en juicio civil.

En forma coherente, el artículo 20 inciso $3^{\circ}$ del D.L. No 211 (1973, 2009) dispone que "las acciones contempladas en esta ley" (sin precisar si son las civiles o las sancionatorias) prescriben en tres años "contado desde la ejecución de la conducta atentatoria de la libre competencia en que se fundan". Este plazo era de sólo dos años en el texto original de la Ley No 19.911 (2003), y fue aumentado a tres años por la Ley No 20.361 (2009). Dicho término es interrumpido por requerimiento del Fiscal Nacional Económico o demanda particular ante el Tribunal de Defensa de la Libre Competencia.

La Ley No 20.361 (2009) introdujo el actual artículo 20 inciso $4^{\circ}$, norma que, en relación al artículo 3o letra a), ambos del D.L. No 211 (1973, 2009), dispone una prescripción de cinco años para la acción sancionatoria, con la particularidad que el cómputo no se inicia "mientras se mantengan en el mercado los efectos imputables a la conducta objeto de la acción”. Esto, sin perjuicio de reconocer que el objeto de la acción es "la conducta" y no el "efecto" que ella cause; y de tratarse indiscutiblemente de una acción sancionatoria y no civil.

Por su parte, el artículo 20 inciso 5o del D.L. No 211 (1973, 2009) establece una suerte de prescripción de la pena (similar a la del artículo 93 No 7 y artículos 97-99, todos del Código Penal).

Finalmente, el artículo 20 inciso 7 o del D.L. No 211 (1973, 2009) vuelve a cometer un innecesario error de redacción (y conceptual) al disponer que "sin perjuicio de las disposiciones generales, las acciones civiles derivadas de un atentado a la libre competencia prescriben en el plazo de cuatro años, contado desde que se encuentre ejecutoriada la sentencia definitiva". Ello es incoherente con el resto de la propia norma y, siendo cierto que el legislador puede fijar el dies a quo donde estime apropiado, no lo es menos que el espíritu general de la legislación, tanto en materia civil como penal, es que la prescripción se cuente desde el hecho (incluso desde la manifestación del daño en muy contados casos, pero jamás desde la sentencia). Pero, además, es una disposición innecesaria, ya que conforme al artículo 20 inciso $3^{\circ}$ del D.L. No $211(1973,2009)$ el plazo se haya interrumpido desde el requerimiento o demanda, por lo que su cómputo no se reinicia sino que una vez que concluye el acto interruptor (que es el juicio) por lo que siempre era posible aplicar el plazo de cuatro años del artículo 2332 computado desde el acto contrario a la libre competencia, e interrumpido entre la fecha del requerimiento o demanda y aquella de la sentencia ejecutoriada.

5) Por último, merece una mención especial, aunque en definitiva no llegara a ser ley a causa de un veto presidencial cuando ya había sido aprobada por el 
Congreso, la interesante discusión doctrinal y legislativa sobre la responsabilidad civil extracontractual del Estado que se produjo en la discusión de la Ley No 19.653, sobre Probidad Administrativa, de 14 de diciembre de 1999. Además de las múltiples referencia hechas a la naturaleza y límites de tal responsabilidad, y a sus vinculaciones con la prescripción del artículo 2332, debe consignarse la aprobación parlamentaria (en definitiva vetada) de introducir en la Ley No 18.575, Orgánica Constitucional de Bases Generales de la Administración del Estado, de 5 de diciembre de 1986, y en la Ley No 18.695, Orgánica Constitucional de Municipalidades, de 31 de marzo de 1988, sendos preceptos disponiendo que "la acción para perseguir esta responsabilidad patrimonial prescribirá en cuatro años, contados desde la fecha de la lesión" $"$.

Si bien el término "lesión" pudiera entenderse coloquialmente como sinónimo de "daño", es en realidad mucho más acotado, pues, según la definición de la Real Academia de la Lengua, es el "daño o detrimento corporal causado por una herida, un golpe o una enfermedad", esto es, es el perjuicio que se causa en un momento determinado como efecto directo de una acción o situación temporalmente circunscrita. Esto se ve claramente reforzado al tratarse de "la fecha" de la lesión. Así se desprende también en el caso de las "lesiones corporales" tratadas por los artículos 395-403 del Código Penal. Por lo mismo, "lesión” debiera ser interpretado como el "hecho material" que causa un daño.

\section{Conclusiones}

Se ha pretendido discutir durante los últimos años si el dies a quo del artículo 2332, "la perpetración del acto", se refiere al hecho material que causa los daños, o si acaso comprende también el perjuicio, de modo que no hay "acto" antes que el daño se manifieste y sea conocido por la víctima (porque se entiende que sólo entonces la obligación indemnizatoria sería exigible). Dispone el artículo 22 inciso $2^{\circ}$ que, en un caso como éste, el recto sentido de la norma "puede ser ilustrado por medio de otras leyes, particularmente si versan sobre el mismo asunto". Puede concluirse al respecto que:

1. Las inmensa mayoría de las normas análogas (16 de un total de 21) consideran como dies a quo un "hecho", un momento cierto y determinado, una fecha precisa, sin considerar ni la manifestación ni el conocimiento del "daño";

2. Hay 3 normas (de un total de 21) que por la materia que tratan (seguridad humana y medioambiente) consideran como dies a quo el "daño", pero teniendo en cuenta su "manifestación", que también es una fecha cierta y objetiva, aunque indeterminada, sin perjuicio que una de ellas considera, además, un plazo máximo;

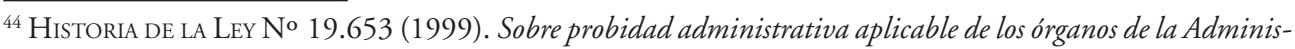
tración del Estado. Biblioteca del Congreso Nacional de Chile, 14 de diciembre de 1999, passim. Disponible en: <http://www.bcn.cl/histley/lfs/hdl-19653/HL19653.pdf> [consulta: 17 mayo 2012].
} 
3. Sólo una norma (de un total de 21) considera como dies a quo la "detección" o "conocimiento" del daño, pero establece un plazo máximo computado desde un momento cierto para que esto se produzca;

4. En los caso en que se utiliza como dies a quo la "manifestación" o "conocimiento" del daño, al tratarse de normas específicas y excepcionales, tal criterio debe interpretarse restrictivamente y no puede ser aplicado por analogía, y

5. Finalmente, en general, los casos dudosos se deben a deficiencias en la técnica legislativa, pero no a la existencia de un principio jurídico diverso a la fijación del dies a quo en un "hecho" cierto.

Estas consideraciones deben ser analizadas junto a los restantes criterios interpretativos, pero es necesario establecer desde ya que conforme el antiguo criterio romano de la interpretatio per aliam legem conjugado con el de substrata materia, y que recoge el artículo 22 inciso $2^{\circ}$, la "perpetración del acto", dies a quo del artículo 2332, debiera interpretarse como el "hecho material" que causa los perjuicios, con independencia de su "manifestación” y con mayor razón todavía de su "conocimiento" por parte de la víctima.

Esta conclusión es relevante desde que está confirmada por una jurisprudencia ampliamente mayoritaria ${ }^{45}$. En una indagación sobre la aplicación del artículo 2332 he logrado encontrar un total de 98 sentencias definitivas dictadas por la Corte Suprema o las Cortes de Apelaciones entre el año 1903 y noviembre de 2011 en las cuales se resuelve en forma más o menos directa sobre el dies a quo de dicha norma ${ }^{46}$. De ellas, una cantidad de 91 , es decir, el 93\%, equiparan la perpetración del acto con "el día en que se cometió el hecho ilícito" o "el acto ilícito generador de los perjuicios" ${ }^{4}$. De las 7 restantes hay 2 que reconocen explícitamente dicho

\footnotetext{
${ }^{45}$ No obstante las reservas que deben tenerse en general respecto a los análisis cuantitativo de jurisprudencia y en especial en el caso chileno, carente de sistematización, y donde aumenta el riesgo de que el universo muestral esté incompleto.

${ }^{46}$ Por la extensión y objeto de este artículo es imposible incluir aquí el listado de sentencias. Está en actual edición una obra monográfica de mi autoría que contiene el análisis cabal de dicha jurisprudencia. Sin perjuicio de lo anterior, se citan a manera ejemplar algunas de las sentencias revisadas.

${ }^{47}$ Sirvan como muestra de la jurisprudencia uniforme durante el último siglo las siguientes sentencias: Corte Suprema, "Rodríguez con Rodríguez", 9 de enero de 1922 (indemnización de perjuicios), Revista de Derecho y Jurisprudencia, t. XXI, sec. 1a, p. 501; Corte Suprema, "Langer con Caja Nacional de Ahorros", 8 de julio de 1935 (indemnización de perjuicios), Revista de Derecho y Jurisprudencia, t. XXXII, sec. 1a, p. 419; Corte Suprema, "Gómez con Ferrocarriles del Estado", 9 de septiembre de 1946 (indemnización de perjuicios), Revista de Derecho y Jurisprudencia, t. XLIV, sec. 1a, p. 130; Corte Suprema, "Fueyo y otros con Urbistondo", 14 de abril de 1953 (indemnización de perjuicios), Revista de Derecho y Jurisprudencia, t. L, sec. 4a, p. 40; Corte Suprema, "Bonssay con Mora", 30 de marzo de 1962 (indemnización de perjuicios), Revista de Derecho y Jurisprudencia, t. LIX, sec. 4a, p. 25; Corte Suprema, "Causa penal contra Allende y otro", 1 de julio de 1971 (indemnización de perjuicios), Revista de Derecho y Jurisprudencia, t. LXVIII, sec. 4a, p. 137; Corte Suprema, "Laboratorio Chile con De la Fuente y otros", 25 de abril de 1986 (indemnización de perjuicios), Fallos del Mes, No 329, p. 149; Corte Suprema, "Massoud con Valdés", 19 de junio de 1990 (indemnización de perjuicios), Rol 318-1989, LegalPublishing No 11016; Corte Suprema, "González y otra con Carrera y otro", 6 de diciembre de 2006 (indemnización de perjuicios),
} 
principio general, aunque argumentan juzgar "casos especiales" a fin de no aplicarlo ${ }^{48}$; hay 3 que, más allá de los términos empleados, en realidad fallan sobre algo diverso ${ }^{49}$; finalmente, hay 2 que fijan el dies a quo en la fecha de la sentencia penal, apartándose de un modo grosero del texto y espíritu del artículo $2332^{50}$.

Lo anterior no impide, ciertamente, que se apliquen las normas que fijan un criterio distinto en los casos precisamente comprendidos por ellas, en conformidad al principio de especialidad (artículos $4^{\circ}$ y 13). Asimismo, el legislador podría eventualmente establecer para determinados casos un dies a quo diverso, mediante el cual privilegie algún elemento distinto a la ocurrencia del "hecho" que provoca consecuencialmente un daño. Sin embargo, ello es improbable, en atención al modo en que se han resuelto las últimas discusiones legislativas en que se ha tratado esta materia.

Finalmente, conviene tener en cuenta que el problema de la prescripción extracontractual no se refiere tanto al conocimiento del daño o al establecimiento de un determinado dies a quo, ni siquiera a la extensión del plazo de prescripción, sino que a la existencia de un plazo máximo. Éste debe necesariamente computarse desde el hecho, pues de lo contrario se iniciará en una fecha que no se sabe si ha de llegar, ni cuándo, como el día en que una persona se entere de haber sufrido un perjuicio, parafraseando el artículo 1081 inciso $4^{\circ}$ del Código Civil. Sólo la existencia de un plazo máximo contado desde el hecho que provoca los perjuicios permite a la institución de la prescripción liberatoria cumplir su función de propender a la seguridad jurídica.

Rol 177-2006, LegalPublishing No 35652; y, Corte Suprema, "Caucoto con Fisco", 29 de noviembre de 2011 (indemnización de perjuicios), Rol 6566-2009.

${ }^{48}$ Corte Suprema, "González y otros con Arellano y otros", 15 de octubre de 2008 (indemnización de perjuicios), Rol 4723-2007; y Corte Suprema, “Tenorio con Fisco”, 21 de diciembre de 2009 (indemnización de perjuicios), Rol 5233-2008.

${ }^{49}$ Corte Suprema, "Wiedma con Conde y otro", 1 de agosto de 1967 (indemnización de perjuicios), Revista de Derecho y Jurisprudencia, t. LXIV, sec. 1a, p. 265; Corte Suprema, "Zuleta con Sociedad General Supply", 4 de enero de 1996 (indemnización de perjuicios), Fallos del Mes, No 446, p. 1899; Corte de Apelaciones de Rancagua, "Silva Torrealba con Corpbanca", 1 de agosto de 2007 (indemnización de perjuicios), Rol 409-2007, LegalPublishing No 36863.

${ }^{50}$ Corte Suprema, "Lagos y otros con García y otros", 25 de septiembre de 2008 (indemnización de perjuicios), Rol 4662-2007; y Corte Suprema, "Baigorri y otra con Fisco", 15 de marzo de 2010 (indemnización de perjuicios), Rol 6-2009. 


\section{BiBLIOGRAFÍA CITADA}

Abeliuk Manasevich, René (1983). Las Obligaciones. Santiago: Editorial Jurídica Ediar-ConoSur, 2a Edición.

Alessandri Rodríguez, Arturo (1943). De la Responsabilidad Extracontractual en el Derecho Civil Chileno. Santiago: Imprenta Universitaria.

Alessandri, Arturo; Somarriva, Manuel y Vodanovic, Antonio (1990). Derecho Civil, Parte Preliminar y Parte General. Santiago: Editorial Jurídica Ediar ConoSur, T. I, 5a Edición.

Alexy, Robert (1989). Teoría de la argumentación jurídica. Madrid: Centro de Estudios Constitucionales.

Barros Bourie, Enrique (2011). "Conceptualismo y vulgarismo en el Derecho civil. Homenaje a los 20 años de las Jornadas Nacionales de Derecho Civil". En: Estudios de Derecho Civil VI: Jornadas Nacionales de Derecho Civil, Olmué, 2010, Figueroa, Gonzalo; Barros, Enrique y Tapia, Mauricio (Coords.), Universidad de Chile, Santiago: AbeledoPerrot LegalPublishing, pp. 21-36.

Corral Talciani, Hernán (2003). Lecciones de Responsabilidad Civil Extracontractual. Santiago: Editorial Jurídica de Chile.

Díaz-Ambrona Bardají, María Dolores (2000). Cuestiones sobre Responsabilidad Civil. En: Estudios de la UNED, Díaz-Ambrona Bardají, María Dolores (Coord.), Universidad Nacional de Educación a Distancia, Madrid.

Díez-Picazo y Ponce de León, Luis (2000). Derecho de Daños. Madrid: Civitas Ediciones, reimpresión de la $1^{a}$ Edición.

Domínguez Águila, Ramón (2004). La prescripción extintiva, Doctrina y jurisprudencia. Santiago: Editorial Jurídica de Chile.

Dorn Garrido, Carlos (2005). "Responsabilidad extracontractual del Estado por actos del Ministerio Público". Revista de Derecho, Consejo de Defensa del Estado, No 13 , s/p.

Elorriaga de Bonis, Fabián (2008). "El día de inicio del plazo de prescripción de una acción indemnizatoria cuando el perjuicio se ha manifestado con posterioridad al hecho que lo origina”. En: Estudios de Derecho Civil III. Jornadas Nacionales de Derecho Civil, Valparaíso, 2007, GuZMÁN BRITO, Alejandro (Ed.), Pontificia Universidad Católica de Valparaíso, Santiago: LegalPublishing, pp. 771-789.

Escalona Riveros, Francisco (1997). La prescripción extintiva civil. Santiago: Editorial Jurídica ConoSur, Fundación Fernando Fueyo.

Fernández Madero, Jaime (2002). Derecho de daños. Nuevos aspectos doctrinales y jurisprudenciales. Buenos Aires: La Ley.

Ferrada Walker, Luis Valentín (2011). “Aspectos históricos del art. 2332 del Código Civil, hacia la recta interpretación del precepto". En: Estudios de Derecho Civil VI: Jornadas Nacionales de Derecho Civil, Olmué, 2010, FigueroA, 
Gonzalo; BARros, Enrique y TAPIA, Mauricio (Coords.), Universidad de Chile, Santiago: AbeledoPerrot LegalPublishing, pp. 719-735.

GuZMÁn BRITO, Alejandro (1992). "La historia dogmática de las normas sobre interpretación recibidas por el Código Civil de Chile”. En: Interpretación, integración y razonamiento jurídico. Conferencias y ponencias presentadas en el Congreso realizado en Santiago y Viña del Mar entre el 23 y 25 de mayo de 1991, Universidad de Chile, Universidad Adolfo Ibáñez, Santiago: Editorial Jurídica de Chile, pp. 41-87.

GuZMÁn BRito, Alejandro (2004). "La doctrina de Jean Domat sobre la interpretación de las leyes". Revista Chilena de Derecho, Universidad Católica de Chile, Santiago, Vol. 31, No 1, pp. 39-68.

GuZMÁn BRito, Alejandro (2007). Las reglas del Código Civil del Chile sobre interpretación de las leyes. Santiago: LexisNexis.

GUZMÁn BRITO, Alejandro (2009). "Las fuentes de las normas sobre interpretación de las leyes del 'Digeste des Lois Civiles' ('Code Civil') de la Luisiana (1808/1825)”. Revista de Estudios Histórico-Jurídicos, No 31, pp. 171-195.

Historia de La Ley No 19.640 (1999). Establece la ley orgánica constitucional del Ministerio Público. Biblioteca del Congreso Nacional de Chile, 15 de octubre de 1999. Disponible en: <http://www.bcn.cl/histley/lfs/hdl-19640/HL19640. pdf> [consulta: 17 mayo 2012].

HistORIA DE LA LEY No 19.653 (1999). Sobre probidad administrativa aplicable de los órganos de la Administración del Estado. Biblioteca del Congreso Nacional de Chile, 14 de diciembre de 1999, passim. Disponible en: <http://www.bcn. cl/histley/lfs/hdl-19653/HL19653.pdf> [consulta: 17 mayo 2012].

Historia DE LA LEY No 19.966 (2004). Establece un régimen de garantías de salud. Biblioteca del Congreso Nacional de Chile, 3 de septiembre de 2004. Disponible en: <http://www.bcn.cl/histley/lfs/hdl-19966/HL\%2019966.pdf> [consulta: 17 mayo 2012].

Historia DE LA LEY No 20.190 (2007). Introduce adecuaciones de indole tributaria e institucional para el fomento de la industria de capital de riesgo y continúa con la modernización del mercado de capitales. Biblioteca del Congreso Nacional de Chile, 5 de junio de 2007. Disponible en: <http://www.bcn.cl/histley/lfs/ hdl-20190/HL20190.pdf> [consulta: 17 mayo 2012].

HistORIA DE LA LEY No 20.308 (2008). Sobre protección a los trabajadores en el uso de productos fitosanitarios. Biblioteca del Congreso Nacional de Chile, 27 de diciembre de 2008. Disponible en: <http://www.bcn.cl/histley/lfs/hdl-20308/ HL20308.pdf> [consulta: 17 mayo 2012].

LunA Yerga, Álvaro et al. (2002). "Reparación in natura y por equivalente: opciones de la víctima en el derecho español". Indret, No 2. Disponible en: <http:// www.indret.com/pdf/083_es.pdf> [consulta: 17 mayo 2012].

Meza Barros, Ramón (2004). Manual de Derecho Civil. De las Obligaciones. Santiago: Editorial Jurídica de Chile, reimpresión de la 9a Edición actualizada. 
Ortúzar Solar, Antonio (1994). "Chile ingresa al derecho ambiental". Revista del Abogado, Colegio de Abogados de Chile, Santiago, julio de 1994.

Pizarro Torrealba, Eduardo y Pino Reyes, Octavio (2001). Responsabilidad civil extracontractual por daño ambiental. Santiago: Editorial Jurídica ConoSur.

RIOSECO ENRÍQUeZ, Emilio (2004). La prescripción extintiva ante la jurisprudencia. Santiago: Editorial Jurídica de Chile, 2a Edición actualizada.

Squella Narducci, Agustín (2005). Andrés Bello. Escritos jurídicos, políticos y universitarios. Santiago: LexisNexis, $2^{\text {a }}$ Edición.

Squella Narducci, Agustín (2006). "Justificar decisiones jurídicas y justificar decisiones judiciales". Revista de Derecho, Universidad Austral de Chile, Vol. XIX, No 1, pp. 277-292.

\section{NORMAS CITADAS}

Código Aeronáutico.

Código Civil.

Código de Comercio.

Código Penal.

Código de Procedimiento Civil.

Constitución Política de la República.

Ley No 15.703, sobre Pesticidas, Diario Oficial, 1 de octubre de 1964, derogada por D.L. No 3.557 (1981).

Ley No 16.744, de Seguro Social contra Riesgos de Accidentes del Trabajo y Enfermedades Profesionales, Diario Oficial, 1 de febrero de 1968.

Ley No 18.045, de Mercado de Valores, Diario Oficial, 22 de octubre de 1981.

Ley No 18.302, Ley sobre Seguridad Nuclear, Diario Oficial, 2 de mayo de 1984.

Ley No 18.415, Ley Orgánica Constitucional de Estados de Excepción, Diario Oficial, 14 de junio de 1985.

Ley No 18.575, Orgánica Constitucional de Bases Generales de la Administración del Estado, Diario Oficial, 5 de diciembre de 1986.

Ley No 18.680, que sustituye Libro III "Del Comercio Marítimo" del Código de Comercio, Diario Oficial, 11 de enero de 1988.

Ley No 18.695, Orgánica Constitucional de Municipalidades, Diario Oficial, 31 de marzo de 1988.

Ley No 18.755, sobre el Servicio Agrícola y Ganadero, Diario Oficial, 7 de enero de 1989.

Ley No 19.300, Ley de Bases Generales del Medioambiente, Diario Oficial, 9 de marzo de 1994.

Ley No 19.301, que modificó diversas normas sobre valores, fondos mutuos, fondos de inversión y similares, Diario Oficial, 19 de marzo de 1994. 
Ley No 19.472, que estableció normas relativas a la calidad de la construcción, Diario Oficial, 16 de septiembre de 1996.

Ley No 19.640, Orgánica Constitucional del Ministerio Público, Diario Oficial, 15 de octubre de 1999.

Ley No 19.653, sobre Probidad Administrativa, Diario Oficial, 14 de diciembre de 1999.

Ley No 19.911, que creó el Tribunal de la Libre Competencia, Diario Oficial, 14 de noviembre de 2003.

Ley No 19.966, sobre Garantías en Salud (Plan de Garantías Explícitas de Salud, GES; ex AUGE), Diario Oficial, 3 de septiembre de 2004.

Ley No 20.016, que estableció normas relativas a la calidad de la construcción, Diario Oficial, 27 de mayo de 2005.

Ley No 20.190, Introduce adecuaciones de índole tributaria e institucional para el fomento de la industria de capital de riesgo y continúa con la modernización del mercado de capitales, Diario Oficial, 5 de junio de 2007.

Ley No 20.308, sobre Protección a los Trabajadores en el Uso de Productos Fitosanitarios, Diario Oficial, 27 de diciembre de 2008.

Ley No 20.361, modifica D.L. No 211, Diario Oficial, 13 de julio de 2009.

Ley No 20.443, modifica Ley General de Urbanismo y Construcciones, Diario Oficial, 23 de noviembre de 2010.

D.L. No 211, Ley de Defensa de la Libre Competencia, Diario Oficial, 22 de diciembre de 1973.

D.L. No 2.222, Ley de Navegación Marítima, Diario Oficial, 31 de mayo de 1978.

D.L. No 3.538, que crea la Superintendencia de Valores y Seguros, Diario Oficial, 23 de diciembre de 1980 .

D.L. No 3.557, Ley sobre Protección Agrícola, Diario Oficial, 9 de febrero de 1981.

D.F.L. No 1 del Ministerio de Economía, Fomento y Reconstrucción, texto refundido D.L. No 211, Diario Oficial, 7 de marzo de 2005.

D.F.L. No 458, Ley General de Urbanismo y Construcciones, Diario Oficial, 13 de abril de 1976.

\section{JURISPRUDENCIA CITADA}

Corte Suprema, "Rodríguez con Rodríguez", 9 de enero de 1922 (indemnización de perjuicios), Revista de Derecho y Jurisprudencia, t. XXI, sec. 1ª, p. 501.

Corte Suprema, "Langer con Caja Nacional de Ahorros", 8 de julio de 1935 (indemnización de perjuicios), Revista de Derecho y Jurisprudencia, t. XXXII, sec. $1^{\text {a }}$, p. 419. 
Corte Suprema, "Gómez con Ferrocarriles del Estado”, 9 de septiembre de 1946 (indemnización de perjuicios), Revista de Derecho y Jurisprudencia, t. XLIV, sec. $1^{\text {a }}$, p. 130.

Corte Suprema, "Fueyo y otros con Urbistondo", 14 de abril de 1953 (indemnización de perjuicios), Revista de Derecho y Jurisprudencia, t. L, sec. 4a , p. 40.

Corte Suprema, "Bonssay con Mora", 30 de marzo de 1962 (indemnización de perjuicios), Revista de Derecho y Jurisprudencia, t. LIX, sec. 4ª p. 25.

Corte Suprema, "Wiedma con Conde y otro", 1 de agosto de 1967 (indemnización de perjuicios), Revista de Derecho y Jurisprudencia, t. LXIV, sec. 1a, p. 265.

Corte Suprema, "Causa penal contra Allende y otro", 1 de julio de 1971 (indemnización de perjuicios), Revista de Derecho y Jurisprudencia, t. LXVIII, sec. 4a, p. 137.

Corte Suprema, "Recurso de queja presentado por Kimpel", 6 de noviembre de 1981 (recurso de queja), Revista de Derecho y Jurisprudencia, t. LXXVIII, sec. $5^{\text {a }}$, p. 326.

Corte Suprema, "Laboratorio Chile con De la Fuente y otros", 25 de abril de 1986 (indemnización de perjuicios), Fallos del Mes, No 329, p. 149.

Corte Suprema, "Massoud con Valdés”, 19 de junio de 1990, (indemnización de perjuicios), Rol 318-1989, Legal Publishing No 11016.

Corte de Apelaciones de Santiago, "Herrera con Sánchez", 31 de enero de 1995 (indemnización de perjuicios), Revista de Derecho y Jurisprudencia, t. XCII, sec. $2^{\mathrm{a}}$, p. 11.

Corte Suprema, "Zuleta con Sociedad General Supply", 4 de enero de 1996 (indemnización de perjuicios), Fallos del Mes, No 446, p. 1899.

Corte Suprema, "Aguirre con Fisco", 3 de noviembre de 1997 (indemnización de perjuicios), Rol 4306-1996, Legal Publishing No 14940.

Corte Suprema, "González y otra con Carrera y otro", 6 de diciembre de 2006 (indemnización de perjuicios), Rol 177-2006, Legal Publishing No 35652.

Corte de Apelaciones de Rancagua, "Silva Torrealba con Corpbanca", 1 de agosto de 2007 (indemnización de perjuicios), Rol 409-2007, Legal Publishing No 36863.

Corte Suprema, "Lagos y otros con García y otros", 25 de septiembre de 2008 (indemnización de perjuicios), Rol 4662-2007.

Corte Suprema, "González y otros con Arellano y otros", 15 de octubre de 2008 (indemnización de perjuicios), Rol 4723-2007.

Corte Suprema, "Tenorio con Fisco", 21 de diciembre de 2009 (indemnización de perjuicios), Rol 5233-2008.

Corte Suprema, "Baigorri y otra con Fisco", 15 de marzo de 2010 (indemnización de perjuicios), Rol 6-2009.

Corte Suprema, "Caucoto con Fisco", 29 de noviembre del 2011 (indemnización de perjuicios), Rol 6566-2009. 
ANEXO

\section{Cuadro comparativo}

\begin{tabular}{|c|c|c|c|c|c|c|c|c|}
\hline No & Norma & Descriptor & Plazo & Dies a quo & Hecho & $\begin{array}{c}\text { Manifestación } \\
\text { del daño }\end{array}$ & $\begin{array}{l}\text { Conocimiento } \\
\text { del daño }\end{array}$ & $\begin{array}{l}\text { Plazo } \\
\text { máximo }\end{array}$ \\
\hline 1 & $\begin{array}{l}\text { Artículo } \\
2332 \text { del } \\
\text { Código } \\
\text { Civil }\end{array}$ & $\begin{array}{l}\text { Norma general } \\
\text { de prescripción } \\
\text { de la acción de } \\
\text { responsabilidad } \\
\text { extracontractual }\end{array}$ & 4 años & $\begin{array}{l}\text { Perpetración del } \\
\text { acto }\end{array}$ & $\mathrm{x}$ & & & \\
\hline 2 & $\begin{array}{l}\text { Artículo } \\
898 \text { inciso } \\
1^{\circ} \text { frase } \\
\text { final del } \\
\text { Código } \\
\text { Civil } \\
\end{array}$ & $\begin{array}{l}\text { Reivindicatoria } \\
\text { convertida en ac- } \\
\text { ción de perjuicios }\end{array}$ & $\begin{array}{l}\text { 2, } 5 \text { ó } 10 \\
\text { años, o } \\
\text { imprescrip- } \\
\text { tible, según } \\
\text { los casos }\end{array}$ & $\begin{array}{l}\text { Inicio de la } \\
\text { posesión }\end{array}$ & $\mathrm{x}$ & & & \\
\hline 3 & $\begin{array}{l}\text { Artículo } \\
920 \text { del } \\
\text { Código } \\
\text { Civil }\end{array}$ & $\begin{array}{l}\text { Acción indemni- } \\
\text { zatoria de accio- } \\
\text { nes posesorias }\end{array}$ & 1 año & $\begin{array}{l}\text { Acto de molestia } \\
\text { o embarazo a } \\
\text { la posesión, } \\
\text { pérdida de la } \\
\text { posesión, último } \\
\text { acto de violencia } \\
\text { o cese de la } \\
\text { clandestinidad, } \\
\text { según los casos }\end{array}$ & $\mathrm{x}$ & & & \\
\hline 4 & $\begin{array}{l}\text { Artículo } \\
928 \text { del } \\
\text { Código } \\
\text { Civil }\end{array}$ & $\begin{array}{l}\text { Acción in- } \\
\text { demnizatoria } \\
\text { de querella de } \\
\text { restablecimiento }\end{array}$ & 6 meses & Acto de violencia & $\mathrm{x}$ & & & \\
\hline 5 & $\begin{array}{l}\text { Artículo } \\
950 \text { del } \\
\text { Código } \\
\text { Civil }\end{array}$ & $\begin{array}{l}\text { Acción indemni- } \\
\text { zatoria por obra } \\
\text { ruinosa }\end{array}$ & 1 aก̃o & $\begin{array}{l}\text { Caída de edifi- } \\
\text { cio, construcción } \\
\text { o árbol }\end{array}$ & $\mathrm{x}$ & & & \\
\hline 6 & $\begin{array}{l}\text { Artículo } \\
175 \text { del } \\
\text { Código Ae- } \\
\text { ronáutico }\end{array}$ & $\begin{array}{c}\text { Daños en super- } \\
\text { ficie causado por } \\
\text { aeronave }\end{array}$ & 1 año & $\begin{array}{l}\text { Ocurrencia de } \\
\text { los hechos }\end{array}$ & $\mathrm{x}$ & & & \\
\hline 7 & $\begin{array}{c}\text { Artículo } 20 \\
\text { de la Ley } \\
\text { No } 18.415 \\
(1985)\end{array}$ & $\begin{array}{c}\text { Daños por estado } \\
\text { de excepción }\end{array}$ & 1 año & $\begin{array}{l}\text { Término del } \\
\text { estado de } \\
\text { excepción }\end{array}$ & $\mathrm{x}$ & & & \\
\hline 8 & $\begin{array}{c}\text { Artículo } 63 \\
\text { de la Ley } \\
\text { No } 19.300 \\
(1994)\end{array}$ & Daño ambiental & 5 años & $\begin{array}{c}\text { Manifestación } \\
\text { evidente del } \\
\text { daño }\end{array}$ & & $\mathrm{x}$ & & $\begin{array}{l}\text { Sin plazo } \\
\text { máximo }\end{array}$ \\
\hline 9 & $\begin{array}{l}\text { Artículo } \\
1249 \text { del } \\
\text { Código de } \\
\text { Comercio }\end{array}$ & $\begin{array}{l}\text { Abordaje marí- } \\
\text { timo }\end{array}$ & $\begin{array}{l}2 \text { ó } 3 \text { años, } \\
\text { según los } \\
\text { casos }\end{array}$ & $\begin{array}{l}\text { Fecha del acci- } \\
\text { dente }\end{array}$ & $\mathrm{x}$ & & & \\
\hline 10 & $\begin{array}{l}\text { Artículo } \\
1248 \text { del } \\
\text { Código de } \\
\text { Comercio }\end{array}$ & $\begin{array}{c}\text { Acción por } \\
\text { responsabilidad } \\
\text { por avería simple } \\
\text { marítima }\end{array}$ & 2 años & $\begin{array}{l}\text { Hecho que causa } \\
\text { el daño }\end{array}$ & $\mathrm{x}$ & & & \\
\hline 11 & $\begin{array}{c}\text { Artículo } \\
146 \text { del } \\
\text { D.L. } \\
\text { No } 2.222 \\
(1978) \\
\end{array}$ & $\begin{array}{c}\text { Derrame de } \\
\text { hidrocarburo (1) }\end{array}$ & 3 años & $\begin{array}{c}\text { Fecha de la } \\
\text { producción del } \\
\text { daño }\end{array}$ & & $\mathrm{x}$ & & $\begin{array}{c}6 \text { años } \\
\text { desde la } \\
\text { fecha del } \\
\text { siniestro }\end{array}$ \\
\hline 12 & $\begin{array}{c}\text { Artículo } 146 \\
\text { del D.L. } \\
\text { No } 2.222 \\
(1978) \\
\end{array}$ & $\begin{array}{c}\text { Derrame de } \\
\text { hidrocarburo (2) }\end{array}$ & 3 años & $\begin{array}{c}\text { Actos que } \\
\text { dan derecho a } \\
\text { reembolso }\end{array}$ & $\mathrm{x}$ & & & $\begin{array}{c}6 \text { años } \\
\text { desde la } \\
\text { fecha del } \\
\text { siniestro }\end{array}$ \\
\hline
\end{tabular}




\begin{tabular}{|c|c|c|c|c|c|c|c|c|}
\hline No & Norma & Descriptor & Plazo & Dies a quo & Hecho & $\begin{array}{c}\text { Manifestación } \\
\text { del daño }\end{array}$ & $\begin{array}{c}\text { Conocimiento } \\
\text { del daño }\end{array}$ & $\begin{array}{l}\text { Plazo } \\
\text { máximo }\end{array}$ \\
\hline 13 & $\begin{array}{c}\text { Artículo 8o } \\
\text { del D.L. } \\
\text { No } 3.557 \\
(1981)\end{array}$ & $\begin{array}{l}\text { Acción de direc- } \\
\text { tamente afectado } \\
\text { contra el SAG } \\
\text { por daños en } \\
\text { fumigación }\end{array}$ & 1 ап̆о & $\begin{array}{c}\text { Manifestación de } \\
\text { perjuicios }\end{array}$ & & $\mathrm{x}$ & & $\begin{array}{l}\text { Sin plazo } \\
\text { máximo }\end{array}$ \\
\hline 14 & $\begin{array}{c}\text { Artículo } 36 \\
\text { del D.L. } \\
\text { No } 3.557 \\
(1981 \\
2008)\end{array}$ & $\begin{array}{l}\text { Acción de terce- } \\
\text { ros contra parti- } \\
\text { culares por daños } \\
\text { en fumigación }\end{array}$ & 1 año & $\begin{array}{c}\text { Detección de los } \\
\text { daños }\end{array}$ & & & $\mathrm{x}$ & $\begin{array}{c}4 \text { años } \\
\text { desde la } \\
\text { aplicación } \\
\text { de } \\
\text { plaguicida }\end{array}$ \\
\hline 15 & $\begin{array}{c}\text { Artículo } 66 \\
\text { de la Ley } \\
\text { No } 18.302 \\
(1984)\end{array}$ & Accidente nuclear & 10 años & $\begin{array}{c}\text { Fecha ocurrencia } \\
\text { o denuncia del } \\
\text { accidente }\end{array}$ & $\mathrm{x}$ & & & \\
\hline 16 & $\begin{array}{c}\text { Artículo } 18 \\
\text { del D.F.L. } \\
\text { No } 458 \\
(1976 \\
2005)\end{array}$ & $\begin{array}{l}\text { Responsabilidad } \\
\text { por construc- } \\
\text { ciones }\end{array}$ & $\begin{array}{l}10,5 \text { ó } 3 \\
\text { años, según } \\
\text { los casos }\end{array}$ & $\begin{array}{l}\text { Recepción } \\
\text { municipal o } \\
\text { inscripción } \\
\text { conservativa }\end{array}$ & $\mathrm{x}$ & & & \\
\hline 17 & $\begin{array}{c}\text { Artículo } \\
172 \text { inciso } \\
2^{\circ} \text { de la Ley } \\
\text { No } 18.045 \\
\text { (1981, } \\
2007) .\end{array}$ & $\begin{array}{l}\text { Uso de informa- } \\
\text { ción privilegiada }\end{array}$ & 4 años & $\begin{array}{l}\text { Fecha divulga- } \\
\text { ción al mercado } \\
\text { de información } \\
\text { privilegiada }\end{array}$ & $\mathrm{x}$ & & & \\
\hline 18 & $\begin{array}{c}\text { Artículo } 5^{\circ} \\
\text { inciso } 2^{\circ} \\
\text { de la Ley } \\
\text { No } 19.640 \\
(1999)\end{array}$ & $\begin{array}{c}\text { Responsabilidad } \\
\text { estatal por con- } \\
\text { ductas injustifica- } \\
\text { damente erróneas } \\
\text { o arbitrarias } \\
\text { del Ministerio } \\
\text { Público } \\
\end{array}$ & 4 años & $\begin{array}{l}\text { Fecha de la ac- } \\
\text { tuación dañina }\end{array}$ & $\mathrm{x}$ & & & \\
\hline 19 & $\begin{array}{c}\text { Artículo } 40 \\
\text { de la Ley } \\
\text { No } 19.966 \\
(2004)\end{array}$ & $\begin{array}{l}\text { Acción indem- } \\
\text { nizatoria contra } \\
\text { prestadores de } \\
\text { servicios de salud }\end{array}$ & 4 años & $\begin{array}{l}\text { Acción u } \\
\text { omisión }\end{array}$ & $\mathrm{x}$ & & & \\
\hline 20 & $\begin{array}{l}\text { Artículo } \\
20 \text { inciso } \\
3^{\circ} \text { del D.L. } \\
\text { No } 211 \\
(1973 \\
2009)\end{array}$ & $\begin{array}{l}\text { Acción indem- } \\
\text { nizatoria por } \\
\text { atentado a libre } \\
\text { competencia (1) }\end{array}$ & 3 años & $\begin{array}{l}\text { Ejecución de la } \\
\text { conducta aten- } \\
\text { tatoria a la libre } \\
\text { competencia }\end{array}$ & $\mathrm{x}$ & & & \\
\hline 21 & $\begin{array}{c}\text { Artículo } \\
20 \text { inciso } \\
7^{\circ} \text { del D.L. } \\
\text { No } 211 \\
(1973 \text {, } \\
2009)\end{array}$ & $\begin{array}{l}\text { Acción indem- } \\
\text { nizatoria por } \\
\text { atentado a libre } \\
\text { competencia (2) }\end{array}$ & 4 años & $\begin{array}{l}\text { Ejecutoriedad } \\
\text { de sentencia } \\
\text { definitiva }\end{array}$ & $\mathrm{x}$ & & & \\
\hline
\end{tabular}

